investigation. If the investigation includes a white blood cell count this may give a clue to the diagnosis. There is usually an absolute and relative lymphocytosis, and many of the lymphocytes are atypical. ${ }^{6}$ The diagnosis of infectious mononucleosis will at once be thought of, but the Paul-Bunnel test proves negative. Liver function tests may show a rise in transaminases, but there is no rise in bilirubin and the patient is not jaundiced. The case is one of "Paul-Bunnel-negative mononucleosis." Virological and serological investigations should be carried out.

The virus is most often isolated from the urine, but pharyngeal secretions, saliva, and faeces should also be cultured on human diploid fibroblast tissue cultures. Circulating leucocytes may also be cultured, ${ }^{7}$ and for this 15 to $20 \mathrm{ml}$ of heparinized blood is required. The virus may grow slowly, so that cultures should be kept for at least one month and be examined for cytopathic changes twice weekly, though by direct immunofluorescent methods virus may sometimes be detected within 72 hours. $^{8}$

Antibody to cytomegalovirus may be titrated by complement-fixation and indirect haemagglutination tests. ${ }^{7}$ As patients seldom consult the doctor early in their illness and as there may be delay in diagnosis when they do, antibody titres are often already high when the first serum test is carried out and there may be no rise in titre in a second specimen. Cytomegalovirus macroglobulin, if present, indicates recent infection and may be detected by an indirect fluorescent antibody test. ${ }^{9}$ Tests for Epstein-Barr virus antibody are negative, as is the Paul-Bunnell test for heterophile antibody. Both these tests are positive in infectious mononucleosis.

Cytomegalovirus infection should be considered in patients with unexplained fever. They are not usually seriously ill, but departures from the common picture do occur. Some patients may present with jaundice, ${ }^{10}$ myocarditis, ${ }^{7}$ pneumonitis, ${ }^{6}$ or, rarely, polyneuritis. ${ }^{7}$ The "Paul-Bunnell-negative mononucleosis" syndrome is well recognized in patients after transfusions, ${ }^{11}$ heart surgery, ${ }^{12}$ or renal transplants, ${ }^{13}$ and in old, debilitated patients suffering from chronic disease cytomegalovirus may act as an opportunistic invader causing unexplained outbursts of fever.

${ }^{1}$ Krugman, S., and Ward, R., Infectious Diseases of Children and Adults, 5 th edn. St. Louis, C. V. Mosby, 1973.

2 Weller, T. H., in Viral and Rickettsial Infections of Man, 4th edn., ed. F. L. Horsfall and I. Tamm. London, Pitman, 1965.

${ }^{3}$ Hanshaw, J. B., Postgraduate Medicine, 1964, 35, 472.

4 Weller, T. H., and Hanshaw, J. B., New England fournal of Medicine, 1962, 266, 1233.

5 Christie, A. B., Infectious Diseases: Epidemiology and Clinical Practice, 2nd edn. Edinburgh, Churchill Livingstone, 1973.

- Klemola, E., Annals of Internal Medicine, 1973, 79, 267. . T. D. Y., Annals of Internal Medicine, 1973, 79, 153.

8 Anderson, C. H., and Michaels, R. H., Lancet, 1972, 2, 308.

- Hanshaw, J. B., Steinfeld, H. J., and White, C. J., New England Yournal of Medicine, 1968, 279, 566.

10 Lamb, S. G., and Stern, H., Lancet, 1966, 2, 1003.

1 Kaariainen, L., Klemola, E., and Paloheimo, J., British Medical fournal, 1966, 1, 1270.

12 Smith, D. R., British Medical Yournal, 1964, 1, 945.

13 Nagington, J., Fournal of Hygiene Cambridge, 1971, 69, 645.

\section{Cot Deaths}

Out of every 1,000 infants born in Britain, 12 die during the first month of life, many from gross anomalies and easily recognizable disease; but of the 990 or so survivors another 2 at least will die suddenly and unexpectedly between the first and twelfth months of life. ${ }^{1}$ In absolute numbers these unexpected deaths from sudden infant death syndrome (S.I.D.S.) probably amount to at least 1,800 in Britain each year-more than a third of all post-neonatal deaths. ${ }^{2}$

Most infants who die in this way seem to have been healthy or only mildly unwell on the day before death. Death occurs silently, suddenly, and unobserved, usually during sleep, the child being found lifeless, without evidence of struggle, on average six hours after last being seen alive. Increasing awareness of this syndrome is now a cause of anxiety to many mothers. The aetiology of cot deaths remains obscure. Much of the evidence comes from epidemiological sources. Over $60 \%$ of cot deaths occur between the 4 th and 16th weeks of life. ${ }^{1}$ There is a seasonal incidence with a peak in the winter months and a low point in August. ${ }^{13}$ Affected infants tend to come from social classes III, IV, V. Mothers tend to be younger and to have larger families than average for their age. Boys are affected more ${ }^{4}$ than girls to the extent of three to two.

Analysis of clinical histories shows that upper respiratory tract infection had been noted in up to $40 \%$ of affected infants within the two weeks preceding death. ${ }^{4}$ Nearly half of all cases had been recently discharged from hospital, had been under medical care, or had been thought to be unwell in the week before death. ${ }^{3} \mathrm{~A}$ high proportion of affected infants had been artificially fed ${ }^{6}$ and a higher than expected incidence of cot deaths in siblings has been reported. ${ }^{5}$ Overlaying and smothering are seldom causes of cot death.

C. D. Protestos and colleagues have recently examined the obstetric and perinatal histories of 135 children with S.I.D.S. in whom necropsy was carried out by a paediatric pathologist. ${ }^{7}$ These histories were contrasted with those of the next infants born in the same maternity units as the cot death cases. Some of the earlier epidemiological findings were confirmed and some fresh data emerged. The mothers of the dead infants had blood group patterns with a higher incidence of groups $\mathrm{O}, \mathrm{B}$, and $\mathrm{AB}$ and a lower incidence of group $\mathrm{A}$; reasons for hospital delivery were more often related to abnormal previous pregnancy and complications of pregnancy; mothers of affected infants suffered more frequently from influenza and antepartum haemorrhage during their pregnancies; more of them had received anaesthesia at the time of delivery, had had a short second stage in labour, had given birth to twins, or had defaulted in keeping clinic appointments. The mean birth weight of the affected babies was lower than in controls, more had had symptoms (including dyspnoea) during the postnatal period, had received incubator care, and had been bottle fed on discharge.

Postmortem examination of infants with S.I.D.S. has shown an adequate cause of death, such as pneumonia, acute bronchiolitis, or gastroenteritis in $25 \%$ to $50 \%$ of cases. ${ }^{18} 9$ Viruses have been isolated from $38 \%$ of cases (not always with associated viraemia) as opposed to a $16 \%$ isolation rate from controls. ${ }^{10}$ In about $15 \%$ of cases coming to necropsy evidence of regurgitation and inhalation of stomach contents has been found and in about $20 \%$ of cases petechial haemorrhages have been shown to be present in the region of the sinus node or internodal conducting tissues:11 it is difficult to say whether either of those changes relate to cause or effect. In the majority of cases, however, no specific disease is found or there is minimal pathological change, such as minor pharyngeal inflammation or non-specific tissue changes of a general character which do not adequately explain the sudden death. ${ }^{7}$

Theories put forward to explain cot deaths, or contributory factors adduced, include anaphylaxis to cows' milk re- 
gurgitated and aspirated during sleep ${ }^{12}$-and it has been suggested that this may be associated with familial IgA deficiency; $;^{13}$ sudden and overwhelming infection which kills the infant before specific histological changes have occurred; nasal obstruction, which in infants who are preferential nose breathers may cause apnoea and asphyxia; ${ }^{14}$ magnesium deprivation $;^{15}$ deficiency of selenium and vitamin $\mathrm{E}^{2}$; and non-traumatic atlantoid dislocation. ${ }^{16}$ The possibility that dangerous concentrations of $\mathrm{CO}_{2}$ may build up in carry-cots has been largely discounted. ${ }^{17}$ There is increasing support for the view that a variety of disorders in infancy may culminate in a final common mode of death. This may be of the nature of acute asphyxia resulting from glottic spasm or ventricular failure due to breakdown of the incompletely developed neural control or the conductive mechanisms of the heart. ${ }^{18}$

Where does present knowledge lead us in the prevention of this distressing condition? It may enable us to identify those infants who are at greater risk. The infant most likely to succumb is a low-birth-weight infant from a poor family born after antepartum haemorrhage and anaesthesia to a young mother who already has several children; such an infant is likely to be artificially fed, may have been unwell during the previous fortnight, and is at maximum risk if he is put to bed with an upper respiratory tract infection.

When cot death occurs the parents must be given sympathy and supportive advice to sustain them against the psychological trauma engendered by guilt feelings based on prevalent but now discounted theories of parental carelessness. ${ }^{9}$

\footnotetext{
1 Department of Health and Social Security, Reports on Public Health and Medical Subjects, 1970, 125, 46.

Teare, D., Nursing Mirror, 1973, 136, 18.

${ }^{3}$ Froggatt, P., Lynas, M. A., and MacKenzie, G., British fournal of Preventive and , Social Medicine, 1971, 25, 119.

Bergman, A. B., Ray, G., Pomeroy, M. A., Wahl, P., and Beckwith, J. B., Pediatrics, $1972,49,860$.

Valdes-Dapena, M. A., Pediatrics, 1967, 39, 123.

' Carpenter, R. G., and Shaddick, C. W., British fournal of Preventive and Social Medicine, 1965, 19, 1.

${ }^{7}$ Protestos, C. D., Carpenter, R. G., McWheeny, P. M., and Emery J. L. Archives of Disease in Childhood, $1973,48,835$.

${ }^{8}$ Richards, I. D. G., and McIntosh, H. T., Archives of Disease in Childhood, 1972, 47, 697 .

9 Emery, J. L., British Medical fournal, 1972, 1, 612.

10 Ray, C. G., Beckwith, J. B., Hebestreit, N.' M., and Bergham, A. B., Fournal of the American Medical Association, 1970, 211, 619.

${ }^{11}$ Ferris, J. A. J., British Medical fournal, 1973, 2, 23.

12 Parish, W. E., Barrett, A. M., Coombs, R. R. A., Gunther, M., and Camps, F. E., Lancet, 1960, 2, 1106.

13 Matthews, T. S., and Soothill, J. F., Lancet, 1970, 2, 893.

14 Shaw, E. B., American fournal of Diseases of Children, 1968, 116, 115.

15 Caddell, J. L., Lancet, 1972, 2, 258.

16 Englander, O., British Medical fournal, 1971, 4, 625.

12 Eolton, D. P. G., Cross, K. W., and McKettrick, A. C., British Medical fournal, 1972, 4, 80 .

18 Dawes, G. S., American fournal of Cardiology, 1968, 22, 469.
}

\section{N.H.S. Family Planning}

Family planning seems fated to create public controversy. The introduction of a comprehensive family planning service into the N.H.S. is proving no exception. Last summer a determined House of Lords voted it into the N.H.S. Reorganisation Act despite Government opposition. ${ }^{1}$ Having accepted this enforced change of policy the Government was then faced with the problems of putting it into practicenamely finding the money and agreeing a scheme with N.H.S. doctors that covered social as well as medical need.
The Representative Body accepts the value of family planning and is prepared to see a comprehensive service as part of the N.H.S. ${ }^{2}$ Indeed, doctors have been regularly advising patients who need contraception for medical reasons. Furthermore, several enterprising local health authorities have in recent years pioneered a free contraceptive service on social as well as medical grounds. So there is no substantial medical opposition in principle to this extension of the N.H.S. For many years, too, the Family Planning Association has run clinics staffed by their own doctors at which patients paid fees for advice, appliances, and drugs. The work of these clinics is now to be taken over by the N.H.S.; but how much of it will be done by general practitioners, how much by hospitals, and how much by area health authority clinics outside hospitals no one yet seems to know.

So two questions need answers: can this additional work be done with existing resources without sacrificing some other services to patients? Is the Government prepared to pay doctors for the extra work? The answer to the first question is almost certainly No, as the Negotiating Subcommittee of the Central Committee for Hospital Medical Services makes clear in a statement in the Supplement ( $p$. 16). On the second question the Department of Health seems to be facing both ways, replying Yes to general practitioners $^{3}$ but behaving coyly about meeting consultants. In defending this paradox Whitehall may invoke the legal differences between the N.H.S. contracts of consultants and family doctors, but such double talk is blatantly unfair.

The general practitioners' negotiators have, rightly, insisted that general practitioners should have a separate contract for such work, which, as Dr. Cameron has unequivocally stated, ${ }^{4}$ is outside general medical services. That contract, agreed between the profession and the Health Departments, has gone to the Review Body for pricing. In the present economic climate the "price" may not be to family doctors" liking but at least they will have a negotiating baseline for the future. Unhappily, senior hospital staff remain in limbo, hence the strong reaction of their representatives. They argue, reasonably, that consultants' terms and conditions of service exclude social family planning, pointing out that this type of work is distinct from extra duties resulting from advances in medical science and techniques which are normally absorbed within the contract.

Progress towards organizing a feasible scheme has been slow enough to raise doubts whether the new service could start on 1 April. The General Election has created more uncertainty and it is more than possible that the Government will ask for the existing arrangements to continue on an ad hoc basis until the new administration has completed negotiations with the profession and others concerned. Such a delay will create difficulties, not least for the Family Planning Association. Nevertheless it may be quietly welcomed by the Treasury, who if a workable scheme is to be launched must find more resources, for it would be a sharp step backwards for the N.H.S. to spread existing facilities even more thinly. Hospital staff might then find themselves carrying out social sterilization at the expense of patients with hernias or prolapses. That is surely not what the community wants.

\footnotetext{
1 Hansard, 25 June 1973, Col 17600.

2 British Medical fournal Supplement, 1972, 3, 83.

3 British Medical Fournal, Supplement, 1974, 1, 6.

+ British Medical fournal, Supplement, 1973, 2, 61.
} 